\title{
Computer network rumours prove hard to kill
}

Washington. It is the rumour that will not die. Every six months or so, subscribers to Internet are warned about a plan by the US Federal Communications Commission (FCC) to impose a tax or other surcharge on modems and telecommunications users. Prompted by the messages to complain about the fee, hundreds of other Internet users fire off angry letters to Washington that describe the dire consequences of such a price increase.

It is an impressive display of citizenship. It is also completely wrong. There is no such proposal for a modem tax or 'usage fee'. There has not been one for half a decade.

"Please help us", begs Kathie Kneff, chief of the FCC's informal complaints and public inquiries branch. Her office put out a statement debunking the story in January 1990 , but the flood continues unabated. Last month, the FCC was getting between 150 and 200 letters a day from computer network users incensed by the 'proposal'. The House of Representatives subcommittee on telecommunications still gets between 20 and 30 letters daily.

For the record, there was an FCC proposal in 1987 to impose something akin to a modem fee. But it was dropped after telecommunications services such as Compuserve mobilized a letter-writing campaign that dumped more than 10,000 complaints on the FCC. Over the past few years, the FCC has also been slowly implementing rules under the so-called Open Network Architecture regulations that could theoretically impose a fee for accessing computer network services. But the FCC has specifically created an exemption for such end-user network access, on the grounds that 'rate shock' would disrupt the rapidly growing computer telecommunications community.

No one seems to know where the latest round of rumours began, nor who started it. Andrew Blau, a telecommunications expert at the private Washington-based Electronic Frontiers Foundation, chalks it up to "cyberspace folklore". It is an electronic village version of the old 'urban myth', such as the baby alligator flushed into a New York City sewer that developed into a 20 foot man-eater.

Blau blames the persistent rumour on a misguided sense of civic responsibility on the part of some network user who finds an old warning when searching through databases of archived messages. The user may distribute the message (which typically consists of a short description of the 'proposal' and its dire consequences, a fill-in-the-blanks form letter and a list of congressional names and addresses) to other users, not realizing

\section{EXPO site to become science park}

Munich. When EXPO'92 shuts down in October, more than 200 hectares of pavilion-clad park land along Seville's river Guadalquivir will be turned into a science park. The scheme is part of a programme by the European Communities (EC) to support research and development in southern Europe.

The $\mathrm{EC}$ is donating $670,000 \mathrm{ECU}$ (US $\$ 850,000$ ) to help develop the park in the Cartuja area of Seville. Much of the money will be used to facilitate the cooperative venture between three other EC-supported science and technology parks in the Mediterranean basin, at Montpellier (France), Bari (Italy) and Malaga (Spain). Experts from each of these sites will be pooling their experience to offer practical advice to the Cartuja Science Park, scheduled to open next spring.

Juan-Carlos Moreno, whose company,
Sociedad Cartuje '93, coordinates future plans for the EXPO site, says that 20 companies, including Rank-Xerox and Cruzcampo, one of Spain's largest breweries, have expressed interest in the science park. They are now waiting for a government decision, expected within the next couple of months, on financial incentives. At an annual land rental cost of 2,000 pesetas (US\$20) a square metre, the price is lower than comparable science and technology parks in northern Europe.

But cost is not the only incentive for prospective tenants. Dieter Eckert of Siemens, the German-based international electronics company, says that the price of land has not played a serious part in its decision to locate in Cartuje. Already well-established in Spain, Siemens is eager to have a development centre there as well. that it is either five years old or simply a mistaken relic from the last round of rumours.

Although the 'facts' change subtly in each round of messages, most of them mention that the proposed modem fee was discussed on a San Francisco talk show and in the New York Times. No dates are ever given and, as far as the FCC has been able to determine, neither the article nor the talk show ever existed.

The FCC seems to be particularly vulnerable to rampaging rumour. Another legend that has made life miserable at the commission is that Madeline Murray O'Hare, the head of the US atheist movement, has petitioned the FCC to ban religious broadcasting. This story - which the FCC has explained countless times is utterly unfounded - has resulted in several hundred thousand letters.

To the computer network community's credit, each wave of speculation and warning is usually countered eventually by some user who actually bothers to make a few telephone calls and investigate before printing out the form letter and sending it off. One of those who have sought to stem the latest wave is David Dean, an anthropology graduate student at the City University of New York. As an unwitting propagator of the initial modem tax rumour, Dean felt an obligation to check out some of the sceptical replies he got from those who had seen it all before. After a call to Congress and the Electronic Frontier Foundation, Dean redeemed himself by uploading another message clarifying the situation.

According to FCC and congressional officials, the latest wave seems to be slowly dying out, no doubt due to efforts like Dean's. But it will, they predict, be back within a year. Christopher Anderson

\section{Max Planck stays put}

Munich. The Max Planck Society has abandoned its 40-year-old plan to move to Berlin once the city regained its status as Germany's capital. At the society's annual meeting in Dresden, president Hans Zacher announced that the society, which runs major research institutes all over Germany, would stay in Munich "for the foreseeable future".

Plans to move to Germany's historical capital, first announced in 1952, reflected the ideological desire to occupy the home of the society's predecessor, the KaiserWilhelm Society, in a reunited Germany. But as the cost of the recent reunification has delayed plans to move government offices to Berlin until 1997, the Max Planck Society has settled on legally registering itself in Berlin.

Alison Abbott 